\title{
THE EFFECT OF SEWAGE SLUDGE APPLICATIONS ON YIELD AND QUALITY OF VETCH + BARLEY MIXTURE*
}

\author{
Seda RAJABI KHIABANI, A. Esen CELEN** \\ Ege University, Faculty of Agriculture, Dept. of Field Crops, Bornova, Izmir, TURKEY \\ * This work is part of the PhD thesis \\ **Corresponding author: esen.celen@ege.edu.tr
}

Received: 22.06 .2020

\begin{abstract}
This study was conducted in Bornova experimental fields of Department of Field Crops, Faculty of Agriculture, University of Ege, Turkey during 2015 and 2016, in order to determine the effects of treated sewage sludge on yield and quality of vetch + barley mixture. The experimental design was in Randomized Complete Block Design (RCBD) with four replications. In the trial, $10 \mathrm{t} \mathrm{ha}^{-1}, 20 \mathrm{t} \mathrm{ha}^{-1}$ and $30 \mathrm{t} \mathrm{ha}^{-1}$ treated $^{-}$ sewage sludge were used in addition to the control and mineral fertilizer application and some characteristics such as plant height, botanical composition, fresh herbage yield, dry matter rate, dry matter yield, the rates of crude protein and crude ash, the yields of crude protein and crude ash, Neutral Detergent Fiber (NDF) and Acid Detergent Fiber (ADF) rates were determined. The results showed that plant height, botanical composition, fresh herbage yield and dry matter yield were significantly affected by the applications. In the study which the highest vetch and barley plant height and dry matter yield were obtained with sewage sludge applications of 20 and $30 \mathrm{t} \mathrm{ha}^{-1}$, the highest vetch rate in botanical composition was obtained with control and mineral fertilizer applications. Sewage sludge applications of 10, 20 and $30 \mathrm{tha}^{-1}$ gave the highest barley rate in botanical composition. Dry matter rate, crude ash rate and yield, crude protein rate and yield, NDF and ADF rates were not affected by mineral fertilizer and sewage sludge applications. When the results are evaluated in general, according to the soil analysis results and heavy metal amounts from the sewage sludge, it is concluded that 20 or $30 \mathrm{t} \mathrm{ha}^{-1}$ sewage sludge can be used in vetch + barley mixtures.
\end{abstract}

Keywords: Mineral fertilizer, mixture, quality, sewage sludge, yield

\section{INTRODUCTION}

Animals need roughage $(60 \%$ roughage - $40 \%$ concentrate) for their daily diets (Anonymous, 2016). Therefore, livestock sector has to meet a significant part of its quality roughage need from meadow-pasture and forage crop production. Vetch + barley mixtures are one of the most important forage crops grown for this purpose. Asci et al. (2015) reported that in intercropping systems; sowing, cultivar, species used in mixtures and mixture rate may significantly affect the hay yields, quality of the mixture and the interspecies competition in mixtures.

Intensive and uncontrolled use of chemical fertilizers causes pollution of the surface and groundwater. Recently, in many countries, the use of organic fertilizers is preferred against soil, water and environmental pollution caused by the excessive use of chemical fertilizers. This has increased the need and use of organic fertilizers (Rosenberg, 2006).
One of the methods that increase the quality and productivity of agricultural soils in order to increase the forage crops farming is use of organic matter. Considering the scarcity of organic matter in soils (Yalcin et al., 2011), it is known that mixing organic sources into the soil is very important. In addition to good agricultural practices, organic matter is very important in traditional agriculture, too. The benefits of using sewage sludge such as low cost and increased yield are stated by many researchers (Barbeiro et al., 2013; Collivignarelli et al., 2015; Iticescu et al., 2015; Schiopu et al., 2015; Uzun et al., 2011; Sumner, 2000). The aim of this research was to investigate the effect of treated sewage sludge (TSS) on yield and quality of vetch + barley mixture.

\section{MATERIALS and METHODS}

\section{Experimental site}

The experiment was carried out during 2015-16 and 2016-17 growing seasons at Bornova experimental fields $\left(38^{\circ} 27.236 \mathrm{~N}, 27^{\circ} 13.576 \mathrm{E}\right)$ of Agricultural Faculty of 
Ege University, Izmir, Turkey. The experimental site is in the Western Anatolia region of Turkey, where the Mediterranean climate prevails with a long-term mean annual temperature of $18.1{ }^{\circ} \mathrm{C}$. Long-term mean annual precipitation is $688.9 \mathrm{~mm}$, representing about most of rainfalls during the winter and spring (Table 1). Longterm mean annual potential evapotranspiraten is 1,570 $\mathrm{mm}$.

Table 1. Average temperature (AT) and total precipitation (TP) of the experimental area at Bornova - İzmir, Turkey

\begin{tabular}{|c|c|c|c|c|c|c|c|c|}
\hline & \multicolumn{2}{|c|}{$\begin{array}{c}\text { Long Year } \\
\text { Average } \\
(\mathbf{1 9 7 0 - 2 0 1 3 )}\end{array}$} & \multicolumn{2}{|c|}{2015} & \multicolumn{2}{|c|}{2016} & \multicolumn{2}{|c|}{2017} \\
\hline & $\begin{array}{l}\text { AT } \\
\left({ }^{\circ} \mathbf{C}\right)\end{array}$ & $\begin{array}{c}\mathbf{T P} \\
(\mathbf{m m})\end{array}$ & $\begin{array}{l}\text { AT } \\
\left({ }^{\circ} \mathbf{C}\right)\end{array}$ & $\mathbf{T P}(\mathbf{m m})$ & $\begin{array}{l}\text { AT } \\
\left({ }^{\circ} \mathbf{C}\right)\end{array}$ & $\mathbf{T P}(\mathbf{m m})$ & $\begin{array}{l}\text { AT } \\
\left({ }^{\circ} \mathbf{C}\right)\end{array}$ & $\mathbf{T P}(\mathrm{mm})$ \\
\hline January & 9.0 & 112.2 & 8.9 & 125.1 & 8.5 & 161 & 6.3 & 237.6 \\
\hline February & 9.2 & 99.7 & 9.5 & 101.9 & 13.6 & 76.5 & 10.4 & 55.6 \\
\hline March & 11.8 & 82.9 & 11.7 & 75.6 & 13.8 & 103 & 13.3 & 72.2 \\
\hline April & 16.1 & 46.4 & 15.9 & 46.4 & 18.9 & 12.8 & 16.6 & 15.7 \\
\hline May & 21.0 & 25.4 & 20.8 & 30.9 & 21.2 & 28.2 & 21.7 & 27 \\
\hline June & 26.0 & 7.5 & 25.6 & 9.8 & 27.7 & 9.2 & 26.5 & 1.8 \\
\hline July & 28.3 & 2.1 & 28.0 & 1.8 & 29.9 & 1.2 & 29.8 & 1.4 \\
\hline Agust & 27.9 & 1.7 & 27.7 & 2.6 & 29.4 & 3.0 & 29.4 & 0.3 \\
\hline September & 23.9 & 19.9 & 23.7 & 15.0 & 25.1 & 6.4 & 24.6 & 0.9 \\
\hline October & 19.1 & 43.2 & 18.8 & 45.3 & 19.2 & 1.4 & 18.8 & 45.7 \\
\hline November & 13.8 & 109.7 & 14.0 & 94.8 & 14 & 101 & 13.3 & 62.1 \\
\hline December & 10.5 & 137.9 & 10.6 & 141.1 & 6.8 & 15.2 & 11.8 & 73.9 \\
\hline Ave.-Total & 18.1 & 688.9 & 17.9 & 690.3 & 19.0 & 518.6 & 18.5 & 594.2 \\
\hline
\end{tabular}

The soil of the experiment area is clay loam, slightly alkaline, low in organic matter, calcareous, high in available $\mathrm{Cu}, \mathrm{Zn}$ and $\mathrm{Mn}$, low in Fe. Some selected properties and total heavy metal concentratens in TSS used in the experiment is given in Table 2.

Table 2. Analysis results of the treated sewage sludge used in the experiment

\begin{tabular}{llllll}
\hline $\mathbf{p H}$ & & $\mathbf{N a}$ & $\mathrm{mg} \mathrm{kg}^{-1}$ & 1390,5 \\
$\mathbf{E C}$ & $\mu \mathrm{S} \mathrm{cm}{ }^{-1}$ & 1945 & $\mathbf{F e}$ & $\mathrm{mg} \mathrm{kg}^{-1}$ & 12754,96 \\
Organic matter & $\%$ & 51,20 & $\mathbf{C u}$ & $\mathrm{mg} \mathrm{kg}^{-1}$ & 176,5 \\
Organic C & $\%$ & 29,66 & $\mathbf{Z n}$ & $\mathrm{mg} \mathrm{kg}^{-1}$ & 1376,59 \\
Lime & $\%$ & 5,35 & $\mathbf{M n}$ & $\mathrm{mg} \mathrm{kg}^{-1}$ & 350 \\
$\mathbf{N}$ & $\%$ & 2,99 & $\mathbf{N i}$ & $\mathrm{mg} \mathrm{kg}^{-1}$ & 69,73 \\
$\mathbf{P}$ & $\%$ & 0,2275 & $\mathbf{P b}$ & $\mathrm{mg} \mathrm{kg}^{-1}$ & 17,44 \\
$\mathbf{K}$ & $\%$ & 0,34 & $\mathbf{C r}$ & $\mathrm{mg} \mathrm{kg}^{-1}$ & 112,53 \\
$\mathbf{C a}$ & $\%$ & 6,36 & $\mathbf{C d}$ & $\mathrm{mg} \mathrm{kg}^{-1}$ & 2,83 \\
$\mathbf{M g}$ & $\%$ & 2,04 & $\mathbf{B}$ & $\mathrm{mg} \mathrm{kg}^{-1}$ & 16,1 \\
\hline
\end{tabular}

\section{Field experiment}

Five different applications including the control, mineral fertilizer, TSS sewage sludge $10 \mathrm{t} \mathrm{ha}^{-1}, 20 \mathrm{t} \mathrm{ha}^{-1}$ and $30 \mathrm{t} \mathrm{ha}^{-1}$ as dry matter were compared in a field trial arranged in the Randomized Complete Block Design with four replications in 2015 and 2016. The plot dimensions were $2 \mathrm{~m}$ width and $5 \mathrm{~m}$ length and each parcel had 10 rows of $20 \mathrm{~cm}$ spacing. The TSS used in the experiment was obtained from the wastewater treatment plant of Metropolitan Region, Izmir city. TSS was added to the soil at the rates of $10 \mathrm{t} \mathrm{ha}^{-1}, 20 \mathrm{tha}^{-1}$ and $30 \mathrm{t} \mathrm{ha}^{-1}$ as dry matter. Also $60 \mathrm{~kg} \mathrm{~N}, 60 \mathrm{~kg} \mathrm{P}_{2} \mathrm{O}_{5}, 60 \mathrm{~kg} \mathrm{~K} 2 \mathrm{O}$ ha $(15.15 .15$ composed fertilizer) were applied to the mineral fertilizer plots at the same time and was mixed into the soil to 15 $\mathrm{cm}$ dept. Vetch (Vicia sativa L.) cv. Alper $\left(150 \mathrm{~kg} \mathrm{ha}^{-1}\right)$ and barley cv. Sancak (50 kg ha-1) (Tan and Serin, 1996) were sown by hand on December 08, 2015 in first year and on December 12, 2016 in second year. Weeds were removed by hand as needed. Since the experiment was conducted during the winter months, there was no additional irrigation. Necessary measurements were made before harvest. After removing one row from each side and $50 \mathrm{~cm}$ from each side as an edge effect, the remaining area was harvested and the yields per hectar were found by calculation from the data obtained. In the trial following characters were evaluated: Plant height, botanical composition, fresh herbage yield, dry matter rate, dry matter yield, crude protein rate, crude protein yield, crude ash rate, crude ash yield, NDF and ADF rates. 
In each plot, plant heights was measured from harvest area before harvest. Botanical composition was found by cutting the plants in the $0.5 \mathrm{~m}^{2}$ quadrates randomly placed in each plot, separating into leguminous and gramineous elements and proportioning to the total weight. Forage on a area of $6.4 \mathrm{~m}^{2}$ in each plot was cut at $5 \mathrm{~cm}$ above ground level approximately and fresh weight recorded. Harvested fresh herbage $(1 \mathrm{~kg})$ was dried to a constant weight at $105^{\circ} \mathrm{C}$ during $24 \mathrm{~h}$ for calculating dry matter. Crude protein $(\mathrm{CP})$ and crude fash $(\mathrm{CA})$ were determined using standard techniques as prescribed by AOAC (1991). The neutral detergent fibre (NDF) and acid detergent fibre (ADF) concentrations were analysed by the sequential detergent analysis method (Goering and VanSoest, 1970).

\section{Statistical analysis}

Data were analyzed using the Statistical Package for the Social Sciences (SPSS) version 17 (SPSS, 2008). LSD test was used to find if differences in the treatments were significant at $\mathrm{P} \leq 0.05$ (Steel and Torrie, 1980).

\section{RESULTS AND DISCUSSION}

The significance of the $\mathrm{F}$ values of year, application and application $\mathrm{x}$ year ineraction variance components for measured characteristics are shown in Table 3. It could be seen in Table 3 that the differences between years were significant for vetch plant height, vetch rate in botanical composition, barleyb rate in botanical composition, fresh herbage yield, dry matter rate, dry matter yield, crude ash yield, crude protein yield and NDF rate at 0.01 level. Applications also had significant $F$ values for vetch plant height, vetch botanical composition, barley plant height, barley botanical composition and fresh herbage yield at 0.01 level. Dry matter yield was affected from applications at 0.01 statistically important level. Application $\mathrm{x}$ year was significant for crude ash rate at 0.01 significant level.

Table 3. The significance of F Values of the variation for characteristics based on the analysis of variance combined over two years

\begin{tabular}{|c|c|c|c|}
\hline Characteristic & Year & Application & Application x Year \\
\hline Vetch plant height & $* *$ & $* *$ & n.s \\
\hline Vetch botanical composition (\%) & $* *$ & $* *$ & n.s \\
\hline Barley plant height & n.s & $* *$ & n.s \\
\hline Barley botanical composition (\%) & $* *$ & $* *$ & n.s \\
\hline Fresh herbage yield $\left(\mathrm{t} \mathrm{ha}^{-1}\right)$ & $* *$ & $* *$ & n.s \\
\hline Dry matter rate $(\%)$ & $* *$ & n.s & n.s \\
\hline Dry matter yield $\left(\mathrm{t} \mathrm{ha}^{-1}\right)$ & $* *$ & $*$ & n.s \\
\hline Crude ash rate $(\%)$ & n.s & n.s & $*$ \\
\hline Crude ash yield ( $\left.\mathrm{t} \mathrm{ha}^{-1}\right)$ & $* *$ & n.s & n.s \\
\hline Crude protein rate $(\%)$ & n.s & n.s & n.s \\
\hline Crude protein yield $\left(\mathrm{t} \mathrm{ha}^{-1}\right)$ & $* *$ & n.s & n.s \\
\hline $\operatorname{NDF}(\%)$ & $* *$ & n.s & n.s \\
\hline $\operatorname{ADF}(\%)$ & n.s & n.s & n.s \\
\hline
\end{tabular}

\section{Plant height}

In the first year, a higher plant height for vetch was obtained with $106.8 \mathrm{~cm}$, while in the second year a lower plant height was obtained with $76.7 \mathrm{~cm}$. Considering the fertilizer applications, the highest vetch plant heights were 101.1 and $94.8 \mathrm{~cm}$ with $30 \mathrm{t}$ and $20 \mathrm{t} \mathrm{ha}^{-1}$ sewage sludge applications respectively, while the plant height of the control application of $85.1 \mathrm{~cm}$ gave the smallest value. Only fertilizer applications were effective in barley plant height, and the highest plant heights were obtained as 113.8 and $107.9 \mathrm{~cm}$ from $30 \mathrm{t}$ and $20 \mathrm{t} \mathrm{ha}^{-1}$ sludge applications, respectively. The lowest plant height was taken from control plots with $86.1 \mathrm{~cm}$ (Table 4). $10 \mathrm{t} \mathrm{ha}^{-1}$ sludge application and mineral fertilizer application were also included in the same statistical group. The fact that vetch heights in the second year are lower than that of the first year can be attributed to the higher botanical composition of barley in the second year, as can be seen in Table 4. Vetch may have been suppressed by barley. This can be attributed to the fact that barley emerged faster than vetch, took benefit from high January rainfall and developed better than vetch. In addition, it can be said that due to the slow release of nitrogen in the sewage sludge, the plant could be taken benefits from this nitrogen continuously. It was found in the study that sewage sludge was more effective on barley plant height than vetch. This may be attributed to the better response of grain to nitrogen. Karaca and Cimrin (2002), who investigated the effect of nitrogenous and phosphorus fertilizer applications on the plant height of common vetch + barley mixture, stated that nitrogen fertilization significantly increased the height of common vetch and barley plants. Investigating the effect of sewage sludge on turf grass, Celebi et al. (2010) found that sewage sludge application in many features including plant height caused an increase. 
Table 4. Means of plant height and botanical composition of vetch and barley for applications

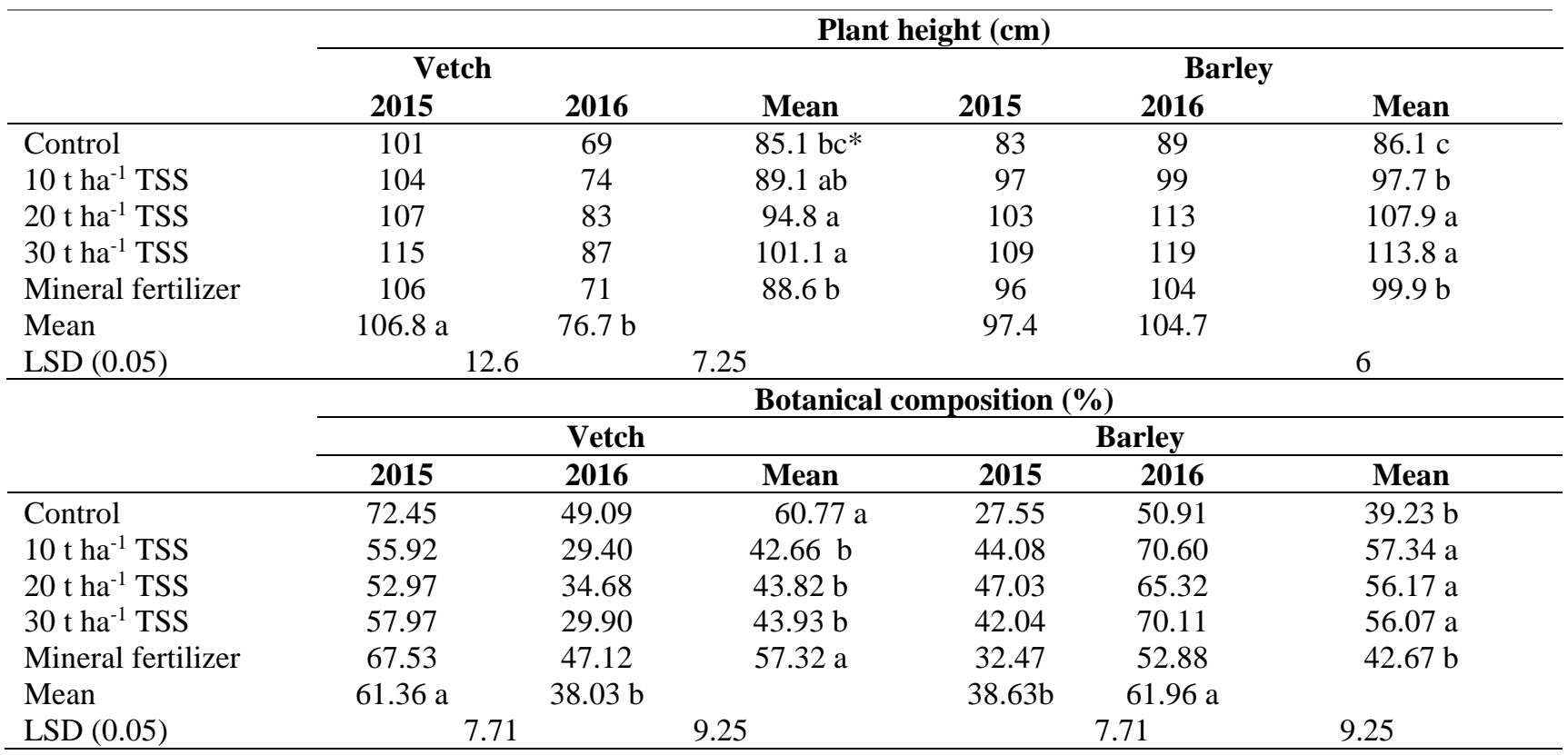

* Denotes significant differences at $\mathrm{p} \leq 0.05$

\section{Botanical composition}

While the botanical composition rate of vetch was $61.36 \%$ in the first year, botanical composition rate of $38.03 \%$ was obtained in the second year. In terms of fertilizer applications, the highest vetch botanical composition rates were obtained from control and mineral fertilizer applications with $60.77 \%$ and $57.32 \%$ respectively, while the all sewage sludge applications gave lower botanical composition rates. While a low botanical composition rate of $38.63 \%$ was obtained in the first year for barley, a higher botanical composition rate of $61.96 \%$ was obtained in the second year. In terms of fertilizer applications, the highest botanical composition rates were obtained from sewage sludge applications varying between $56.07-57.34 \%$, while the lowest composition rates were obtained from control and mineral fertilizer applications with 39.23 and $42.67 \%$, respectively (Table 4). Karaca and Cimrin (2002) found that nitrogen and phosphorus fertilization had no statistical effect on the botanical composition of the vetch + barley mixture based on fresh weight. While the researchers determined the rate of common vetch as $54.6 \%$ in control plots, they emphasized that this rate decreased to $50.8 \%$ at $60 \mathrm{~kg} \mathrm{ha}^{-1}$ nitrogen dose. The researchers commented that this may be related to the need of barley to nitrogen and thus the increased competitiveness of barley. Plant height naturally affects the total weight of the plant and therefore the botanical composition rate. Second year planting was done with a delay of a few days due to climate and soil conditions. In December of the second year and in the following few months, the air temperature remained well below the first year. In addition, in January 2017, following the second year of sowing, a very high rainfall of $237.6 \mathrm{~kg}$ was observed. It can be said that the rapid emergence of barley and its rapid development affected the vetch plants and therefore the botanical composition rates of the vetch remain low.

\section{Fresh herbage yield, dry matter rate and dry matter yield}

In the first year $48.04 \mathrm{t} \mathrm{ha}^{-1}$ fresh herbage yield was obtained, while in the second year a lower fresh herbage yield (24.41 $\left.\mathrm{t} \mathrm{ha}^{-1}\right)$ was obtained. Considering the applications, the highest yield was obtained from $30 \mathrm{t} \mathrm{ha}^{-1}$ sewage sludge application as $34.63 \mathrm{t} \mathrm{ha}^{-1}$, while all other applications were in the same group and gave lower fresh herbage yield. The highest dry matter rate $(28.58 \%)$ was obtained from second year applications. The dry matter rate of the first year $(24.16 \%)$ was lower than the second year. Dry matter rates varied between $26.02 \%$ and $26.63 \%$ according to fertilizer applications and there was no statistical difference between them. Year effect is also important on dry matter yield, and the highest dry matter yield was obtained from first year cultivation as $11.50 \mathrm{t}$ $\mathrm{ha}^{-1}$. The second year gave lower dry matter yield $(6.98 \mathrm{t}$ $\left.\mathrm{ha}^{-1}\right)$. In terms of fertilizer applications, on dry matter yield, it is seen that the highest yields were obtained from 30 and $20 \mathrm{t} \mathrm{ha}^{-1}$ sewage sludge applications as $10.59 \mathrm{t} \mathrm{ha}^{-1}$ and $9.28 \mathrm{tha}^{-1}$, respectively (Table 5). 
Table 5. Means of fresh herbage yield, dry matter rate and dry matter yield of vetch + barley mixture for applications

\begin{tabular}{|c|c|c|c|c|c|c|c|c|c|}
\hline & \multicolumn{3}{|c|}{$\begin{array}{c}\text { Fresh herbage yield } \\
\left(\mathrm{t} \mathrm{ha}^{-1}\right)\end{array}$} & \multicolumn{3}{|c|}{$\begin{array}{c}\text { Dry matter rate } \\
(\%)\end{array}$} & \multicolumn{3}{|c|}{$\begin{array}{c}\text { Dry matter yield } \\
\left(\mathrm{t} \mathrm{ha}^{-1}\right)\end{array}$} \\
\hline & 2015 & 2016 & Mean & 2015 & 2016 & Mean & 2015 & 2016 & Mean \\
\hline Control & 45.60 & 21.00 & $33.30 b^{*}$ & 24.54 & 28.71 & 26.63 & 11.20 & 6.05 & $8.62 \mathrm{~b}$ \\
\hline $10 \mathrm{t}$ ha- 1 TSS & 47.72 & 23.05 & $35.38 \mathrm{~b}$ & 25.03 & 28.00 & 26.52 & 11.36 & 6.52 & $8.94 \mathrm{ab}$ \\
\hline $20 \mathrm{t}$ ha- 1 TSS & 46.67 & 26.80 & $36.73 \mathrm{~b}$ & 23.57 & 28.48 & 26.02 & 10.99 & 7.57 & $9.28 \mathrm{a}$ \\
\hline $30 \mathrm{t}$ ha-1 TSS & 52.55 & 29.60 & $41.08 \mathrm{a}$ & 23.75 & 29.21 & 26.48 & 12.52 & 8.65 & $10.59 \mathrm{a}$ \\
\hline Mineral fertilizer & 47.67 & 21.60 & $34.63 \mathrm{~b}$ & 23.94 & 28.49 & 26.21 & 11.41 & 6.10 & $8.76 \mathrm{~b}$ \\
\hline Mean & $48.04 \mathrm{a}$ & $24.41 \mathrm{~b}$ & & $24.16 \mathrm{~b}$ & $28.6 \mathrm{a}$ & & $11.50 \mathrm{a}$ & $7 \mathrm{~b}$ & \\
\hline $\operatorname{LSD}(0.05)$ & \multicolumn{2}{|c|}{3.25} & 3.5 & \multicolumn{2}{|c|}{1.56} & & \multicolumn{2}{|c|}{0.98} & 1.31 \\
\hline
\end{tabular}

* Denotes significant differences at $\mathrm{p} \leq 0.05$.

There are many studies showing that sewage sludge increases efficiency (Binder et al., 2002; Hirel et al., 2007; Cocarta et al., 2017; Delibacak et al, 2016). Cimrin et al. (2001) found that nitrogen and phosphorus fertilization increased the fresh matter yield of the mixture and emphasized that $60 \mathrm{~kg} \mathrm{~N}^{-1}$ application gave good results. Keskin et al. (2012) investigated the effect of sewage sludge application on leguminous + gramineous mixtures and reported that sewage sludge leads to an yield increase. Researchers stated that sewage sludge can be used as a nitrogen source in such mixtures. As for the low yields in the second year, it may be possible to interpret this difference in terms of plant height and botanical composition values. When Table 4 is examined, it will be seen that the second year vetch plant height and botanical composition rates are quite low compared to the first year. This, ultimately affected the fresh herbage yield and lower yields were obtained in the second year. The year differences on dry matter rates can be attributed to the differences in the botanical composition of the plants, as explained above. Yüksek dozda arıtma çamuru uygulamasıyla baklagil+buğdaygil karışımını kuru madde veriminin arttığını birçok araştırıcı belirtmiştir (Ayub et al., 2008; Karaca and Cimrin, 2002; Keskin et al., 2012).

\section{Crude ash rate and yield}

The highest crude ash rate $(8.82 \%)$ was obtained with $10 \mathrm{t} \mathrm{ha}^{-1}$ application in the first year of the study. The lowest crude ash content was obtained as $6.75 \%$ in the first year. In the second year, the highest crude ash rate was obtained as $7.61 \%$ with $20 \mathrm{t} \mathrm{ha}^{-1}$ sludge application, while the lowest crude ash content was obtained with $30 \mathrm{t}$ $\mathrm{ha}^{-1}$ sludge application as $6.66 \%$ (Table 6). Bozkurt et al. (2001) reported that the amount of $\mathrm{P}, \mathrm{Fe}, \mathrm{Mn}$ and $\mathrm{Cu}$ increased in plants by using sewage sludge in barley. Karaca and Cimrin (2002) emphasized that nitrogen increased the $\mathrm{P}$ amount in common vetch + barley mixture. As a result, we can say that since these elements form the crude ash content, the sludge application increased the crude ash rate. Although there was a slight decrease in the botanical composition rate of the vetch with sewage sludge applications (Table 4) the higher crude ash rate compared to the control can be attributed to the presence of many other nutrients other than nitrogen in the content of the sludge.
Regarding the crude ash yield, the highest crude ash yield $\left(0.91 \mathrm{t} \mathrm{ha}^{-1}\right)$ was obtained in the first year, while a lower ash yield was obtained as $0.50 \mathrm{t} \mathrm{ha}^{-1}$ in the second year (Table 6). The mean of the applications varied among 0.65 and $0.80 \mathrm{t} \mathrm{ha}^{-1}$. Although there was no significant difference in the rate of crude ash between years, we can attribute the year difference in ash yield to the use of dry matter yield in the calculation of crude ash yield. Because there was a significant difference in dry matter yield between years. Crude ash yield was found by multiplying the dry matter yield with the crude ash rate. The fact that there was no difference in ash yield with sludge application in our study can be attributed to the difference in soil conditions in which the experiment was established.

\section{Crude protein rate and crude protein yield}

Regarding the crude protein contents, there were no significant differences and $13.90 \%$ and $12.38 \%$ values were obtained from the first and second years, respectively. In terms of applications, crude protein rates ranged among 12.52 and $13.84 \%$ (Table 6). Karaca and Cimrin (2002) determined that nitrogen fertilization increased the crude protein rate of common vetch + barley mixture. Although there was no statistically significant difference in protein rate in applications, numerically higher crude protein contents were obtained in sludge and mineral fertilizer applications than control. Therefore, it can be said that our results are compatible with the results of other researchers.

While a higher protein yield was obtained as $1.60 \mathrm{t} \mathrm{ha}^{-}$ ${ }^{1}$ in the first year, a lower yield $\left(0.87 \mathrm{t} \mathrm{ha}^{-1}\right)$ was obtained in the second year. Regarding the applications, protein yields ranged among 1.10 and $1.38 \mathrm{t} \mathrm{ha}^{-1}$. Karaca and Cimrin. (2002) stated that nitrogen fertilizer in the vetch + barley mixture increased the fresh herbage yield and the crude protein rates, thus the protein yield increased. Although the applications had no significant effect on protein yield, sludge and mineral fertilizer applications gave better results than control numerically in our study, too. 
Table 6. Means of crude ash content, crude prtotein content, crude ash yield and crude protein yield of vetch + barley mixture for applications

\begin{tabular}{|c|c|c|c|c|c|c|}
\hline & \multicolumn{3}{|c|}{$\begin{array}{c}\text { Crude ash rate } \\
(\%)\end{array}$} & \multicolumn{3}{|c|}{$\begin{array}{l}\text { Crude ash yield } \\
\left(\mathrm{t} \mathrm{ha}^{-1}\right)\end{array}$} \\
\hline & 2015 & 2016 & Mean & 2015 & 2016 & Mean \\
\hline Control & $8.21 \mathrm{ab}^{*}$ & $7.33 \mathrm{bc}$ & 7.77 & 0.91 & 0.44 & 0.68 \\
\hline $10 \mathrm{t} \mathrm{Ha}^{-1} \mathrm{TSS}$ & $8.82 \mathrm{a}$ & $7.48 \mathrm{bc}$ & 8.15 & 1.00 & 0.49 & 0.75 \\
\hline $20 \mathrm{t} \mathrm{Ha}^{-1} \mathrm{TSS}$ & $6.75 \mathrm{c}$ & $7.61 \mathrm{abc}$ & 7.18 & 0.74 & 0.55 & 0.65 \\
\hline $30 \mathrm{t} \mathrm{Ha}^{-1} \mathrm{TSS}$ & $8.12 \mathrm{ab}$ & $6.66 \mathrm{c}$ & 7.39 & 1.01 & 0.58 & 0.80 \\
\hline Mineral fertilizer & $7.97 \mathrm{ab}$ & $7.60 \mathrm{bc}$ & 7.79 & 0.91 & 0.46 & 0.68 \\
\hline Mean & 7.97 & 7.34 & & $0.91 \mathrm{a}^{*}$ & $0.50 \mathrm{~b}$ & \\
\hline \multirow[t]{3}{*}{$\operatorname{LSD}(0.05)$} & A x Y:1.05 & & & 0.1 & & \\
\hline & \multicolumn{3}{|c|}{$\begin{array}{c}\text { Crude protein rate } \\
(\%)\end{array}$} & \multicolumn{3}{|c|}{$\begin{array}{l}\text { Crude protein yield } \\
\left(\mathrm{t} \mathrm{ha}^{-1}\right)\end{array}$} \\
\hline & 2015 & 2016 & Mean & 2015 & 2016 & Mean \\
\hline Control & 13.19 & 11.86 & 12.52 & 1.47 & 0.72 & 1.10 \\
\hline $10 \mathrm{t} \mathrm{Ha}^{-1} \mathrm{TSS}$ & 14.70 & 12.21 & 13.45 & 1.67 & 0.81 & 1.24 \\
\hline $20 \mathrm{t} \mathrm{Ha}^{-1} \mathrm{TSS}$ & 13.06 & 13.08 & 13.07 & 1.43 & 0.99 & 1.21 \\
\hline $30 \mathrm{t} \mathrm{Ha}^{-1} \mathrm{TSS}$ & 13.70 & 11.91 & 12.80 & 1.73 & 1.03 & 1.38 \\
\hline Mineral fertilizer & 14.85 & 12.84 & 13.84 & 1.70 & 0.78 & 1.24 \\
\hline Mean & 13.90 & 12.38 & & $1.60 \mathrm{a}$ & $0.87 \mathrm{~b}$ & \\
\hline $\operatorname{LSD}(0.05)$ & & & & & & \\
\hline
\end{tabular}

* Denotes significant differences at $\mathrm{p} \leq 0.05$.

\section{$N D F$ and $A D F$ rates}

The highest NDF rate was obtained in the second year as $49.00 \%$. NDF rate was $43.90 \%$ for first year. Applications had no significant effect on NDF rate and values changed among 46.02 and $47.05 \%$. ADF rates varied between $29.98 \%$ and $31.56 \%$ according to the applications (Table 7). Aesen et al. (2004) reported that increasing the legume rate resulted in lower NDF and ADF concentratens for legume-grass. Carr et al. (2004) found that ADF values of barley-pea and oat-pea mixtures were $34.4 \%$ and $36.5 \%$, respectively. Strydhorst et al. (2008) found ADF rates between 28.1 and $26.9 \%$ and
NDF rates varying between 43.5 and $41.8 \%$ in various legume-wheatgrass mixtures such as broad bean-barley, lupen-barley and pea-barley. Based on many studies, Van Soest (1996) reported that legumes and grasses differ from each other in terms of intake and digestibility, and that legumes have low NDF under similar growth conditions than grasses. The low NDF rates in our study, especially in the first year, can be attributed to the high rate of legumes in the botanical composition in the first year, and this is consistent with the findings of many researchers.

Table 7. Means of Neutral Detergent Fiber (NDF) and Acid Detergent Fiber (ADF) contents of vetch + barley mixture for applications

\begin{tabular}{lcccccc}
\hline & \multicolumn{3}{c}{ NDF (\%) } & \multicolumn{3}{c}{ ADF (\%) } \\
\cline { 2 - 7 } & $\mathbf{2 0 1 5}$ & $\mathbf{2 0 1 6}$ & Mean & $\mathbf{2 0 1 5}$ & $\mathbf{2 0 1 6}$ & Mean \\
\hline Control & 44.06 & 48.68 & 46.37 & 30.38 & 31.62 & 31.00 \\
$10 \mathrm{t} \mathrm{Ha}^{-1}$ TSS & 42.67 & 49.36 & 46.02 & 29.70 & 31.93 & 30.81 \\
$20 \mathrm{t} \mathrm{Ha}^{-1} \mathrm{TSS}$ & 44.19 & 48.61 & 46.40 & 29.37 & 30.59 & 29.98 \\
$30 \mathrm{t} \mathrm{Ha}^{-1} \mathrm{TSS}$ & 45.75 & 48.34 & 47.05 & 31.05 & 32.07 & 31.56 \\
Mineral fertilizer & 42.84 & 50.04 & 46.44 & 31.87 & 31.11 & 31.48 \\
Mean & $43.90 \mathrm{~b}$ & $49.00 \mathrm{a}^{*}$ & & 30.47 & 31.46 & \\
LSD $(0.05)$ & 2.75 & & & & & \\
\hline
\end{tabular}

* Denotes significant differences at $\mathrm{p} \leq 0.05$.

\section{CONCLUSION}

For the sustainable use of agricultural areas, the amount of organic matter should be increased. For this, the necessary amount of organic matter should be mixed with the soil to improve the physical and chemical properties of the soil. It is accepted by many researchers that sewage sludge can be used in agricultural activities due to the high organic matter they contain. In addition to high organic matter content, it is accepted by many researchers that sewage sludge contains macro and micro nutrients in sufficient amount to meet the nutrient needs of plants. However, in addition to these beneficial aspects, many studies have shown that sewage sludge can contain different amounts of heavy metals depending on the region and process of production.

In the light of this information, in this study that the effect of different amounts of sewage sludge applications and mineral fertilizer on the yield and quality of vetch + barley mixture was investigated, it was understood that sewage sludge affected the yield, plant heights and botanical composition. On the other hand, dry matter rate, crude ash rate and yield, protein rate and yield, NDF and 
ADF rates were not affected by the applications. When the results are evaluated in general, it is concluded that 20 or $30 \mathrm{t} \mathrm{ha}^{-1}$ sewage sludge can easily be used in vetch + barley mixtures.

\section{ACKNOWLEDGEMENTS}

This research was supported by the Unit of Scientific Research Projects, Ege University (16-ZRF-033). Present manuscript is a part of the $\mathrm{PhD}$ thesis.

\section{LITERATURE CITED}

Aasen, A., V.S. Baron, G.W. Clayton, A.C. Dick and D.H. McCartney. 2004. Swath grazing potential of spring cereals, field pea and mixtures with other species. Canadian Journal of Plant Science 84(4): 1051-1058.

Albayrak, S., M. Turk and O. Yuksel. 2009. Effect of phosphorus fertilization and harvesting stages on forage yield and quality of woolypod vetch. Turkish Journal of Field Crops 14: 30-40.

Anonymous, 2016. Turkey Statistical Institute.

AOAC. 1991. Official methods of analysis. 15th Edition, Association of Official Analytical Chemists, Washington DC.

Asci, O.O., Z. Acar and Y.K. Arici. 2015. Hay yield, quality traits and interspecies competition of forage pea-triticale mixtures harvested at different stages. Turkish Journal of Field Crops 20(2): 166-173.

Ayub, M., A. Tanveer, M.A. Nadeem, M. Tahir and M. Ibrahim. 2008. Effect of seed proportion and nitrogen application on forage yield and nutritive value of barley-pea mixture harvested at different times. Pak. J. Life Soc. Sci. 6(2): 135139.

Barberio G., L. Cutaia and V. Librici. 2013. Treatment and disposal of sewage sludge: comparative life cycle assessment on Italian case study. Environmental Engineering and Management Journal 12(S 11): 7-10.

Binder, D.L., A. Dobermann, D.H. Sander and K.G. Cassman. 2002. Biosolids as nitrogen source for irrigated maize and rainfed sorghum. Soil Sci. Soc. Am. J. 66: 531-543.

Bozkurt, M., I. Yilmaz and K.M. Cimrin. 2001. The use of municipal sewage sludge as a source of nitrogen in winter barley. Y.Y.U. Journal of Agricultural Sciences 7(1): 105110 (in Turkish).

Carr, P.M., R.D. Horsley and W.W. Poland. 2004. Barley, oat, and cereal-pea mixtures as dryland forages in the Northern Great Plains. Agronomy Journal 96: 677-684.

Celebi, Z.S., O. Arvas, R. Celebi and I.H. Yilmaz. 2010. Determination the performance of perennial ryegrass (Lolium perenne L.) in a sod establishment with biosolid. Journal of Tekirdag Agricultural Faculty 7(3): 111-118 (in Turkish).

Cimrin, K.M., S. Karaca and M.A. Bozkurt. 2001. The effect of fertilization on the chemical composition and hay yield of vetch + barley mixture. Journal of Agricultural Sciences 7(4): 32-36 (in Turkish).

Cocarta, D. and A. Badea. 2017. Effect of sewage sludge application on wheat crop productivity and heavy metal accumulation in soil and wheat grain. Environmental Engineering and Management Journal 16(5): 1093-1100.

Collivignarelli, M.C., A. Abba, S. Padovani, M. Frascarolo, D. Sciunnach, M. Turconi and M. Orlando. 2015. Recovery of sewage sludge on agricultural land in Lombardy: current issues and regulatory scenarios. Environmental Engineering and Management Journal 14: 1477-1486.

Delibacak, S. and A.R. Ongun. 2016. Influence of treated sewage sludge applications on corn and succeeding wheat yield and on some properties of sandy clay soil. Turkish Journal of Field Crops 21(1): 1-9.

El-Karamany, M.F., B.A. Bakry and T.A.A. Elewa. 2014. Integrated action of mixture rates and nitrogen levels on quantity and quality of forage mixture from Egyptian clover and barley in sandy soil. Agricultural Sciences 5: 1539-1546.

Goering, H.K. and P.J. VanSoest. 1970. Forage Fiber Analysis (apparatus, reagents, procedures and some applications). USDA Agricultural Handbook No. 379

Hirel. B., J. Le Gouis, B. Ney and A. Gallais. 2007. The challenge of improving nitrogen use efficiency in crop plants: towards a more central role for genetic variability and quantitative genetics within integrated approaches. J. Exp. Bot. 58(9): 2369-2387.

Iticescu. C., L.P. Georgescu, G. Gurau, M. Murarescu, D. Dima, G. Murariu and C. Gheorghies. 2015. Methods to reduce environmental impact of municipal waste water sewage sludge. Environmental Engineering and Management Journal 14(10): 2457-2463.

Karaca, S. and K.M. Cimrin. 2002. Effects of the nitrogen and phosphorus fertilization on the yield and quality of the common vetch (Vicia sativa L.) and barley (Hordeum vulgare L.) mixture. Yuzuncu Y1l University Journal of Agricultural Sciences 12(1):47-52 (in Turkish).

Keskin, B., M.A. Bozkurt and H. Akdeniz. 2012. Effects of sewage sludge and nitrogen fertilizer application on nutrient and heavy metal concentrations in grass-legume mixtures. Igdir Univ. J. Inst. Sci. and Tech. 2(3): 93-102.

Rosenberg, A.S. 2006. Effects of protein aggregates: an immunologic perspective. The AAPS Journal 8(3): 501-7.

Schiopu, A-M., I. Apostol, M. Hodoreanu and M. Gavrilescu. 2007. Solid waste in Romania: management, treatment and pollution prevention practices. Environmental Engineering and Management Journal. 6: 451-465.

SPSS 17.0. 2008. SPSS 17.0 for Windows. Chicago, IL, SPSS Inc.

Steel, R.G.D. and J.H. Torrie. 1980. Principles and Procedures of Statistics: A. Biometrical Approach. 2. ed. New York: McGraw-Hill Publ. Company.

Strydhorst, S.M., J.R. King, K.J. Lopetinsky and K.N. Harker. 2008. Forage potential of intercropping barley with faba bean, lupin, or field pea. Agronomy Journal 100(1): 182190.

Sumner, M.E. 2000. Beneficial use of effluents wastes, and biosolids. Communications in Soil Science and Plant Analysis 31(11-14): 1701-1715.

Tan, M. and Y. Serin. 1996. A study on the determination of optimum mixture rates and cutting stages for different vetch+cereal mixtures. Ataturk Univ. Journal of Agricultural Faculty 27 (4): 475-489 (in Turkish).

Uzun, P. and U. Bilgili. 2011. Possibilities of using sewage sludge in agriculture. Journal of Agricultural Faculty of Uludag University 25(2): 135-146 (in Turkish).

Van Soest, P.J. 1996. Allometry and ecology of feeding behavior and digestive capacity in herbivores: A Review Zoo Biology. 15(5): 455-479.

Yalcin, G., R. Yavuz, M. Yilmaz, K. Taspinar and O. Ates. 2011. Evalution of sewage sludge on agricultural lands. Journal of Engineering and Natural Scinces Sigma 3: 156164 (in Turkish). 